\title{
IMPLEMENTASI STRATEGI KEUNGGULAN BERSAING DAN PENDAMPINGAN REDESAIN KEMASAN DALAM MENINGKATKAN PENJUALAN PADA UKM RITEL DI TANGERANG
}

\author{
Sanny Ekawati ${ }^{1}$, Nur Hidayah ${ }^{2}$, dan Purwanto $^{3}$ \\ ${ }^{1}$ Jurusan manajemen, Universitas Tarumanagara Jakarta \\ Email: sannye@fe.untar.ac.id \\ ${ }^{2}$ Jurusan manajemen, Universitas Tarumanagara Jakarta \\ Email: nurh@fe.untar.ac.id \\ ${ }^{3}$ Jurusan manajemen, Universitas Tarumanagara Jakarta \\ Email: purwanto@fe.untar.ac.id
}

\begin{abstract}
The purpose of the activity is to implement a competitive advantage strategy in the retail business and assistance in making product packaging in increasing retail business sales in the Old Tangerang market. PKM activity is an inspiration from the many retail stores that are not able to increase sales, which is due to competitive advantage strategies that have not been carried out optimally. Given the retail strategy in building a competitive advantage is very necessary for a retailer. The location of the traditional market was chosen because it still needs help from various parties. Including from educational institutions. For this activity partners were chosen because of limited competitive advantage and limited knowledge of the strategy of excellence. In addition, the limitations of partners to build excellence, in assessing internal and external factors in the business environment through SWOT, are indispensable to assist retailers in assessing business excellence. Furthermore, to improve product sales value, better product packaging is needed, this has not been done by partners. The method offered in this activity is the provision of knowledge of retail business excellence strategies, SWOT strategies and packaging design in the form of FGDs, socialization and training. While the assistance is done by making product packaging that is more environmentally friendly. Through this activity will help overcome the problems of partners in doing business better than competitors. Thus the hope can help partners in increasing sales.
\end{abstract}

Keywords: Retail strategy; SWOT; Product Packaging

\begin{abstract}
ABSTRAK
Tujuan kegiatan adalah mengimplementasikan strategi keunggulan bersaing usaha ritel dan pendampingan membuat pengemasan produk dalam meninggkatkan penjualan Usaha Ritel di pasar Lama Tangerang. Kegiatan PKM merupakan inspirasi dari banyaknya toko ritel yang tidak mampu meningkatkan penjulan, yang dikarenakan strategi keunggulan bersaing yang belum dilakukan secara optimal. Mengingat strategi eceran dalam membangun keunggulan bersaing sangatlah diperlukan bagi seorang pengecer. Dipilih lokasi pasar tradisional karena masih sangat membutuhkan bantuan dari berbagai pihak. Termasuk dari lembaga pendidikan. Untuk kegiatn ini mitra yang dipilih karena masih lemahnya keunggulan bersaing, lemahnya pengetahuan akan strategi keunggulan. Selain itu keterbatasan mitra membangun keunggulan, dalam menilai faktor internal dan eksternal di lingkungan usaha melalui SWOT, yang sangat diperlukan untuk membantu peritel dalam menilai keunggulan usaha. Selanjutnya untuk meningkatkan nilai jual produk diperlukan kemasan produk yang lebih baik, hal ini belum dilakukan mitra. Metode yang ditawarkan dalam kegiatan ini adalah pemberian pengetahuan akan strategi keunggulan usaha ritel, strategi SWOT dan desain kemasan dalam bentuk FGD, sosialisasi dan pelatihan. Sedangkan pendampingan dilakukan dengan membuat kemasan produk yang lebih ramah lingkungan. Melalui kegiatan ini akan membantu mengatasi persoalan mitra dalam melakukan usaha secara lebih baik dibandingkan pesaing. Dengan demikian harapannya dapat membantu mitra dalam meningkatkan penjualan.
\end{abstract}

Kata kunci: Strategi ritel, SWOT, Pengemasan Produk.

\section{PENDAHULUAN}

Pedagang ritel harus menetapkan berbagai strategi dalam mempertahankan usaha, Levy \& Weitz (2014). Setiap perusahaan memiliki strategi yang dapat memenangkan persaingan dan mencapai tujuan utama Membangun sebuah eceran adalah membangun keunggulan bersaing dengan menerapkan berbagai strategi yang membentuk keunggulan bersaing yaitu; (Davidson 1998) yang 
terdiri dari Keunggulan Diferensiasi. Setiap perusahaan memilki perbedaan dari pesaing mereka.Perbedaan-perbedaan tersebut akan dinilai oleh pelanggan dan hal inilah yang disebut keunggulan diferensiasi. Keunggulan Spesialis. Sebagai Spesialis mengarah pada varietas yang relatif, luas, dan mutu dari barang yang dijual dan Institusi Penambah Nilai. Mengarah pada seberapa besar nilai yang ditambahkan pada sebuah produk yang dikonsumsi oleh customer melalui peritel (Berman, and Evans,2007; Dunne, Lusch and Griffith, 2002). Morgen dan Hunt (1995) menyarankan bahwa kemampuan usaha ritel menerapkan berbagai strategi tersebut secara efektif akan meningkatkan kinerja dan membuat usaha ritel menikmati keuntungan terus menerus dalam jangka panjang secara lebih baik.

Mitra yang dijadikan tempat kegiatan adalah bergerak dalam bidang perdagangan eceran di pasar lama sudah melakukan usaha selama 15 tahun. Melalui observasi awal yang dilakukan pada mitra teridentifikasi beberapa persoalan mitra antara lain a). Kurangnya pengetahuan mitra dalam menilai keunggulan bersaing. b) kurangnya pengetahuan mitra dalam menganalisis kondisi internal dan ekstewrnal yang terdapat di lingkungan mitra, c). Tidak adanya kemasan produk yang dapat meningkatkan nilai jual produk. Sementara Morgen dan Hunt (1995) menyarankan bahwa, tujuan utama membangun sebuah eceran adalah membangun keunggulan bersaing dengan menerapkan berbagai strategi tersebut dalam membentuk keunggulan bersaing baik dari segi keunggulan differensiasi, specialis dan penambah nilai .Menurut Porter (1990), strategi bersaing sebagai pengembangan formula umum mengenai bagaimana bisnis akan bersaing, tujuan harus dicapai dan kebijakan mencapai tujuan. Konsep strategi bersaing dibangun berdasarkan empat faktor utama sebagai penentu batasan target suatu perusahaan, yaitu: kekuatan \& kelemahan perusahaan, peluang \& ancaman industri, harapan masyarakat serta nilai-nilai dianut oleh eksekutif kunci. Berdasarkan kondisi di atas maka perlu dilakukan kegiatan PKM yang melibatkan dosen dan mahasiswa dari Universitas Tarumanagara.

Perkembngan usaha ritel yang cukup memprihatinkan, selayaknya dirasakan oleh semua pihak. Jika kondisi tersebut dibiarkan, maka lambat laun bisnis ritel tidak akan bertahan dalam waktu yang lama. Ditambah lagi banyak nya pesaing yang terus bermunculan. Kondisi persaingan dapat mengakibatkan banyak usaha ritel tidak dapat melanjutkan usaha. Lain halnya dengan usaha ritel yang mempunyai strategi yang lebih unggul dari pesaing dapat berkembang dan melanjutkan usaha untuk jangka waktu yang panjang. Strategi keunggulan bersaing dan pengemasan produk memainkann peran yang sangat penting dalam membangun keunggulan bersaing. Untuk itu tujuan kegiatan ini dapat mendorong aktivitas usaha ritel agar dapat menggunakan strategi dalam menjalankan usaha ritel untuk jangka waktu yang panjang. Peritel perlu diberikan pemahaman lebih lanjut dalam membangun keunggulan diperlukan strategi differensiasi, specialis dan penambah nilai yang dari observasi masih lemahnya peritel tradisional ini akan ketiga strategi tersebut. Maka dari analisis situasi di atas ,beberapa persoalan yang dihadapi peritel tradisional di pasar lama Tangerang yang menjadi prioritas permasalahan dapat dikelompokkan:

1. Bagaimana memperkenalkan strategi keunggulan bersaing?

2. Bagaimana cara mensosialisasikan strategi keunggulan bersaing ritel?

3. Bagaimana mengidentifikasi faktor internal dan eksternal usaha ritel?

4. Bagaimana merancang strategi SWOT Usaha ritel?

5. Bagaimana mendesain kemasan produk ritel?

6. Bagaimana membuat kemasan yang ramah lingkungan? 


\section{METODE PELAKSANAAN}

\section{A. Solusi Untuk Mengatasi Masalah Mitra}

Berdasarkan hasil diskusi dengan kelompok ritel di Tangerang, prioritas masalah dihadapi oleh kelompok tersebut sebagai berikut:

1. Aspek manajemen, yang terkait dengan strategi keunggulan bersaing ritel, dimana peritel belum memilki pengetahuan akan strategi keunggulan yang perlu dilakukan bagi pengecer dalam menjalankan usaha. Sehingga bisnis ritel banyak yang mengalami kegagalan ditengah jalan. Solusi yang ditawarkan adalah: menjelaskan , mensosialisasikan aspek yang terdapat pada keunggulan differensiasi, spesialis dan keunggulan penambah nilai.

2. Aspek managemen, juga terkait dengan memanfaatkan keuntungan dari kekuatan yang dimiliki dan kesempatan yang ada. Meminimalisi kelemahan dan menimalisi ancaman. Hal tersebut perlu dilakukan untuk dapat unggul dalam bersaing. Solusi yang ditawarkan adalah: Menjelaskan, melakukan sosialisasi pada faktor kekuatan, kelemahan,peluang dan ancaman bagi peritel dalam menjalankan kegiatan usaha.

3. Aspek produksi terkait dengan masalah desain kemasan produk yang dapat meningkatkan nilai jual produk yang ditawarkan kepada konsumen. Dengan menambah suatu atribut produk yang dapat membedakan produk ritel pada pesaing, dilakukan pilot project pada satu usaha ritel sebagai percontohan untuk melakukan kegiatan ini. Solusi ysng ditawarkan adalah: a. Membuat desain kemasan usaha yang disesuaikan dengan hasil studi banding pada ritel moderen, jenis produk yang akan ditawarkan, ukuran produk maupun kondisi pesaing .

\section{B. Model Yang Ditawarkan Untuk Mengatasi Masalah Mitra}

1. Membuat model strategi keunggulan bersaing usaha eceran Membangun sebuah eceran adalah membangun keunggulan bersaing dengan menerapkan berbagai strategi yang membentuk keunggulan bersaing yaitu; (Davidson 1998)

a. Keunggulan Diferensiasi. Setiap perusahaan memilki perbedaan dari pesaing mereka.Perbedaan-perbedaan tersebut akan dinilai oleh pelanggan dan hal inilah yang disebut keunggulan diferensiasi.

b. Keunggulan Spesialis. Sebagai Spesialis mengarah pada varietas yang relatif, luas, dan mutu dari barang yang dijual. Mengacu pada variasi yang relatif, lebar, dan kedalaman barang-barang, sebagai contoh, toko serba ada dan toko potongan adalah spesialisasi barang dagangan rendah sebab mereka membawa variasi banyak orang dan merek produk untuk melayani pasar mereka yang luas. Supermarket makanan dan butik pakaian adalah yang sangat khusus barang dagangannya.

c. Sebagai Institusi Penambah Nilai. Mengarah pada seberapa besar nilai yang ditambahkan pada sebuah produk yang dikonsumsi oleh customer melalui peritel.

2. Membuat penilaian keunggulan bersaing melalui SWOT

SWOT adalah singkatan dari Strengths (kekuatan), Weakness (kelemahan), Opportunities (peluang), Threats (tantangan). Analisa SWOT adalah alat yang digunakan untuk mengidentifikasi isu-isu internal dan eksternal yang mempengaruhi kemampuan kita dalam memasarkan event kita. Analisa SWOT adalah sebuah bentuk analisa situasi dan kondisi yang bersifat deskriptif (memberi gambaran).

3. Model desain kemasan produk

Proses FGD dilakukan juga pada pembuatan kemasan produk ritel terkait dengan: jenis/ukuran kemasan, warna, desain dan spesifikasi lainnya seperti penamaan merek 
dan pelabelan, desain tersebut dibuat sedemikian rupa untuk menarik perhatian konsumen dan membuat differensiasi dengan produk ritel dari peasing. Sebelum proses tersebut dilakukan kegiatan penentuan model pengemasan dilakukan dengan melakukan studi banding pada produk ritel lainnya, yaitu ritel moderen dan pesaing, agar dapat diketahui model pengemasan yang layak dibuat dan diberikan pada peritel. Dengan demikian prosuk riel akan dapat lebih unggul dari pesaing.

\section{Rencana Kegiatan dan Partisipasi Mitra}

Rencana kegiatan dalam rangka pemecahan masalah peritel di Tangerang seperti dalam Tabel 1.

Tabel 1. Rencana Kegiatan \& Partisipasi Mitra Pengecer

\begin{tabular}{|c|c|c|}
\hline No. & Rencana Kegiatan & Partisipasi Mitra \\
\hline 1 & $\begin{array}{l}\text { Observasi awal dengan kelompok usaha ritel di } \\
\text { Tangerang }\end{array}$ & $\begin{array}{l}\text { Mitra responsif/mendukung } \\
\text { mendengar rencana ini. }\end{array}$ \\
\hline 2 & $\begin{array}{l}\text { Membuat FGD tentang panduan strategi } \\
\text { keunggulan ritel yang diperlukan mitra }\end{array}$ & $\begin{array}{l}\text { Tim berdiskusi dengan mitra tentang } \\
\text { starategi perencanaan yang selama ini } \\
\text { dilakukan mitra }\end{array}$ \\
\hline 3 & $\begin{array}{l}\text { Membuat panduan ritel dengan mengkaji aspek } \\
\text { aspek keunggulan differensiasi, spesialis dan } \\
\text { penambah nilai sesuai hasil masukan mitra } \\
\text { melalui FGD }\end{array}$ & $\begin{array}{l}\text { Tim mengkaji aspek aspek yang terkait } \\
\text { dengan strategi perencanaan ritel dengan } \\
\text { secara teoritis dan hasil FGD dengan mitra }\end{array}$ \\
\hline 4 & $\begin{array}{l}\text { Mensosialisasikan SWOT yang sudah disusun } \\
\text { kepada kelompok pengusaha ritel. }\end{array}$ & $\begin{array}{l}\text { Mitra mendengarkan dan berdiskusi } \\
\text { tentang panduan strategi SWOT pada } \\
\text { kelompok mitra }\end{array}$ \\
\hline 5 & $\begin{array}{l}\text { Mendesain pengemasan produk pada peritel yang } \\
\text { dijadikan pilot project }\end{array}$ & $\begin{array}{l}\text { Mitra memberikan kesediaan untuk } \\
\text { Mengemas Produk Dengan Kemasan Yg } \\
\text { Lebih Baik }\end{array}$ \\
\hline 6 & $\begin{array}{l}\text { Mensosialisasikan desain kemasasan i produk } \\
\text { yang akan diawarkan kepada mitra }\end{array}$ & $\begin{array}{l}\text { Mitra memberikan masukan atas desain } \\
\text { kemasan yang menjadi kebutuhan } \\
\text { mendesak untuk dilakukan. }\end{array}$ \\
\hline 7 & $\begin{array}{l}\text { Melakukan pilihan model pengemasan yang akan } \\
\text { ditawarkan kepada mitra }\end{array}$ & $\begin{array}{l}\text { Tim dan mitra memutuskan } \\
\text { untuk melakukan penyusunan desain } \\
\text { yang terkait dengan pengemasan } \\
\text { produk }\end{array}$ \\
\hline
\end{tabular}




\begin{tabular}{|c|c|c|}
\hline 8 & $\begin{array}{l}\text { Melakukan studi banding atas model kemasan yang } \\
\text { ditawarkan. }\end{array}$ & $\begin{array}{l}\text { Mengusulkan perbandingan model } \\
\text { desain produk pada mitra melalui FGD } \\
\text { yang terkait dengan kemasan produk }\end{array}$ \\
\hline 9 & $\begin{array}{l}\text { Membeli peralatan yang diperlukan untuk } \\
\text { membuat kemasan produk }\end{array}$ & $\begin{array}{l}\text { Tim dengan mahasiswa yang } \\
\text { menyusun semua peralatan dan } \\
\text { perlengkapan yang dibutuhkan dalam } \\
\text { membuat kemasan. }\end{array}$ \\
\hline 10 & $\begin{array}{l}\text { Tim mendesain kemasan produk sebagai hasil } \\
\text { keunggulan produk yang ditawarkan kepada mitra }\end{array}$ & $\begin{array}{l}\text { Mitra sharing informasi tentang desain, } \\
\text { ukuran,warna, bentuk dan lainnya } \\
\text { dalam mendesain kemasan. }\end{array}$ \\
\hline 11 & $\begin{array}{l}\text { Menyelesaikan pembuatan kemasan produk untuk } \\
\text { dapat siap digunakan }\end{array}$ & $\begin{array}{l}\text { Mitra dapat menggunakan kemasan } \\
\text { yang bagus dalam melakukan } \\
\text { penjualan produknya. }\end{array}$ \\
\hline 12 & $\begin{array}{l}\text { Penyerahan Panduan strategi keunggulan } \\
\text { bersaing kepada mitra }\end{array}$ & $\begin{array}{l}\text { Mitra menerima model panduan } \\
\text { sederhana tentang strategi keunggulan } \\
\text { bersaing yang harus dilakukan untuk } \\
\text { meningkatkan penjualan produk ritel }\end{array}$ \\
\hline 13 & Penyerahan kemasan produk kepada mitra & $\begin{array}{l}\text { Mitra bersedia menggunakan kemasan } \\
\text { produk dalam menjual produk yang } \\
\text { ditawarkan kepada konsumen }\end{array}$ \\
\hline
\end{tabular}

\section{HASIL KEGIATAN DAN PEMBAHASAN}

\section{A. Profile Pemilik Usaha Ritel}

Usaha ritel didirikan di Pasar lama Tangerang di jalan Jl. Kisamaun, Sukasari. Letak pasar ini sangat strategis. Toko Mimi fashion sudah berdiri 16 tahun. Pada tahun pertama sampai tahun ketiga toko ini awalnya berlokasi di daerah Litang, karena dilokasi tersebut kurang ramai pengunjung sehingga pindah ke pasar Lama. Toko Mimi memiliki empat pegawai, harga sewa ruko toko Mimi sebesar Rp 75.000.000,00/ tahun. Pakaian yang ditawarkan di toko Mimi fashion 
rata-rata pakaian fashion wanita. Mereka melakukan import langsung dari China, penjualan sekitar 20-30pcs/ hari. Promosi yang dilakukan di toko tersebut adalah dengan memberikan diskon. Harga pakaian yang ditawarkan bervariasi sekitar Rp 150.000,00 - Rp 800.000,00. Biasanya pelanggan Mimi fashion banyak melihat merek dan bahan. Toko Mimi memiliki hubungan dengan pelanggan yang baik melalui promosi WOM(Word Of Mouth). Kelemahan toko ini tidak ada online shop dan hanya menjual pakaian wanita. Tingkat penjualan yang paling ramai adalah pada hari libur/ hari raya. Pada hari raya Imlek 2017 lalu, toko Mimi mencapai omset Rp 326.778.000,00. Harapan di toko Mimi fashion ingin membuka cabang baru di tempat lain. Pelayanan yang dilakukan di toko Mimi fashion cukup ramah dan baik.

\section{B. Model Strategi Bersaing Usaha Eceran}

Output pertama yang dirancang adalah mengenalkan strategi bersaing usaha ritel pada mitra. Dimana strategi tersebut dapat membantu mitra dalam menghadapi kondisi persaiangan diantara toko ritel. Untuk itu pelatihan dan sosia;lisasi dilakukan pada pemilik toko dan karyawan Mimi fashion. Karena membangun sebuah eceran adalah membangun keunggulan bersaing dengan menerapkan berbagai strategi yang membentuk keunggulan bersaing (Davidson 1998). Untuk itu perlu mengenalkan berbagai strategi kepada mitra untuk membangun keunggulan bersaing yaitu:

1. Keunggulan Diferensiasi. Setiap perusahaan memiliki perbedaan dari pesaing mereka. Perbedaan-perbedaan tersebut akan dinilai oleh pelanggan dan hal inilah yang disebut keunggulan diferensiasi. Toko Mimi banyak menyediakan produk wanita import dari Cina, ini merupakan salah satu keunggulan, sehingga produk import ini menjadi andalan bagi keunggulan toko Mimi.

2. Keunggulan Spesialis. Sebagai Spesialis mengarah pada varietas yang relatif, luas, dan mutu dari barang yang dijual. Mengacu pada variasi yang relatif, lebar, dan kedalaman barang-barang, sebagai contoh, toko serba ada dan toko potongan adalah spesialisasi barang dagangan rendah sebab mereka membawa variasi banyak orang dan merek produk untuk melayani pasar mereka yang luas. Supermarket makanan dan butik pakaian adalah yang sangat khusus barang dagangannya. Mimi fashion memiliki keunggulan spesifik pada pakaian wanita terutama atasan wanita, dengan gaya anak muda dan orang tua. Namun lebih banyak menyediakan untuk atasan orang tua. Sehingga menjadi lebih spesialis pada kebutuhan fashion untuk orang tua.

3. Sebagai Institusi Penambah Nilai. Mengarah pada seberapa besar nilai yang ditambahkan pada sebuah produk yang dikonsumsi oleh customer melalui peritel.

\section{Membuat Strategi SWOT}

Model kekuatan, kelemahan, peluang dan ancaman pada toko Mimi fashion dapat dilihat pada Tabel 2.

\section{Sosialisasi Keunggulan Bersaing}

Proses FGD dilakukan juga pada pembuatan model panduan strategi keunggulan bersaing usaha eceran. Para pengecer harus mengatur strategi dalam rangka mempertahankan atau mendapatkan dan meningkatkan konsumen mereka. Strategi yang disosialisaskan pada kegiatan PKM adalah memberikan arahan tentrang strategi differensiasi, stategi spesialis dan strategi penambah nilai. Masing masing strategi yang telah diperoleh dari hasil FGD, di soasialisasikan untuk dipertahankan maupun dilakukan perbaikan pada toko Mimi Fashion. Selain itu dilakukan analisis keunggulan bersaing, melalui analisis kekuatan, kelemahan, peluang dan ancaman. Tim berhasil 
menjelaskan strategi SWOT pada pemilik dan karyawan toko. Dengen demikian akan lebih mengetahui strategi yang lebih tepat dalam menjalankan toko ritel dan memenangkan persaingan.

Tabel 2. Kekuatan, Kelemahan, Peluang dan Ancaman pada Toko Mimi Fashion

\begin{tabular}{|c|c|}
\hline $\begin{array}{l}\quad \text { Strength/ Kekuatan } \\
\text { - } \\
\text { Lokasi strategis tepat } \\
\text { ditengah keramaian pasar } \\
\text { - Memiliki toko yang luas } \\
\text { - Kualitas pakaian yang bagus, } \\
\text { import langsung dari Cina. } \\
\text { - Fasilitas lengkap seperti } \\
\text { menyediakan aqua gelas dan ac cctv. }\end{array}$ & $\begin{array}{l}\text { Weakness/ Kelemahan } \\
\text { - Hanya menjual pakaian } \\
\text { wanita } \\
\text { - Harganya relative tinggi } \\
\text { untuk kalangan bawah }\end{array}$ \\
\hline $\begin{array}{l}\text { Opportunity/ Peluang } \\
\text { - } \quad \text { Bisa menguasai pasar karena } \\
\text { tidak ada pesaing } \\
\text { - Lokasi yang strategis membuat toko } \\
\text { ramai dikunjungi }\end{array}$ & $\begin{array}{l}\text { Threatl Ancaman. } \\
\text { - } \\
\text { Akan adanya kenaikan } \\
\text { harga kontrak ruko karena } \\
\text { toko yang ramai } \\
\text { - Karena menjadi pasang baru } \\
\text { akan } \\
\text { adanya pesaing yang } \\
\text { mengikuti tokonya dengan } \\
\text { fasilitas lebih lengkap } \\
\text { - Adanya produk online yang } \\
\text { juga } \\
\text { berpengaruh pada penjualan. }\end{array}$ \\
\hline
\end{tabular}

E. Pendampingan Pembuatan Kemasan Produk

Kegiatan PKM juga dilkakukan untuk pengembangan produk, agar lebih memiliki daya jual yang lebih tinggi. Salah satu kegiatan yang dilakukan adalah membuat kemasan produk, yang tadinya hanya berupa kantong plastik putih biasa yang mudah robek dan tidak memiliki manfaat lebih.serta tidak ramah lingkungan. Kegiatan ini dibuat menciptakan suatu kemasan produk yang menggunakan kain yang berwarna-warni, dan disertai dengan nama merek dan nama toko ritel. Variasi tas kain sebagai kemasan menyesuaikan motif produk ritel yang dijual. Warna dasar kemasan bersifat soft mengikuti dominasi warna produk. Tas kemasan bertuliskan merek berupa toko mimi fashion. Material kemasan tidak mudah robek, tahan lama dan dapat berfungsi sebagai tas bagi konsumen serta ramah lingkungan. Ipteks ditawarkan meliputi langkah berikut:

a. Menyiapkan bahan Spunbond non woven 70 gram

b. Desain model (nama merek, logo, alamat dan lainnya)

c. Bahan dipotong sesuai dengan ukuran yang diinginkan

d. Dilakukan sablon terhadap model yang didesain

e. Dimasukkan dalam mesin lipat dan di press dengan mesin hot press 
Melalui keterlibatan mahasiswa, mempermudah dalam mendesain kemasan produk dengan tujuan untuk meningkatkan daya saing produk. Model desain kemasan seperti Gambar 1.
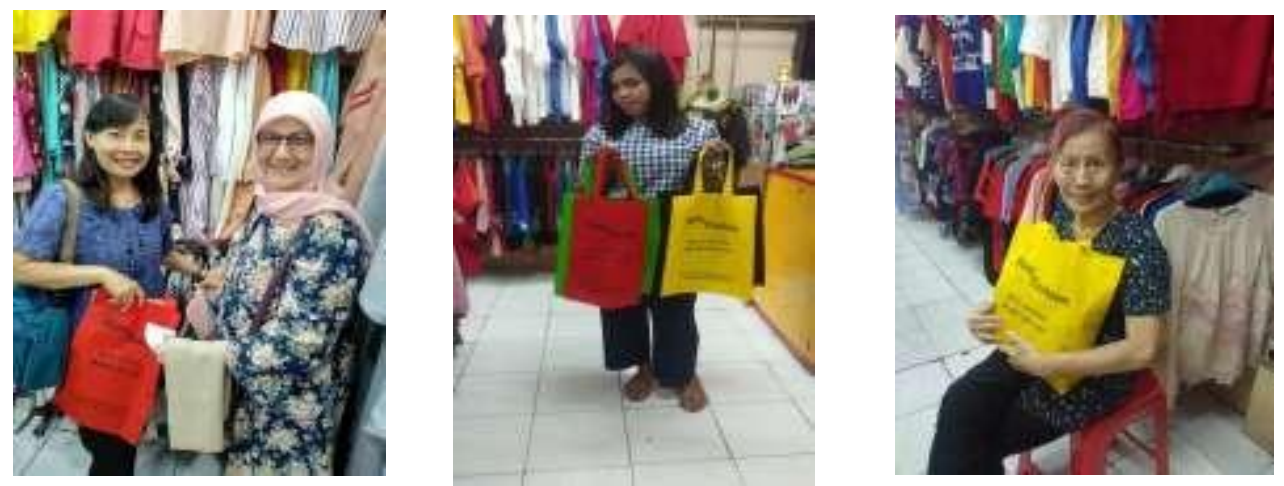

Gambar 1. Model Kemasan Produk Ritel yang Ditawarkan

\section{KESIMPULAN DAN SARAN}

\section{A. Kesimpulan}

Berdasarkan pelaksanaan kegiatan ini, diperoleh kesimpulan sementara sebagai berikut:

1. Panduan strategi perencanaan usaha ritel yang sudah tersusun dengan melakukan FGD, observasi dan wawancara dengan pihak terkait. Sosialisasi skala kecil sudah dilakukan pada beberapa kelompok usaha ritel Mimi Fashion yang terdapat di pasar Lama Tangerang..

2. Pelatihan strategi keunggulan bersaing ritel yang perlu dilakukan dalam menjalankan bisnis secara berkelanjutan dan unggul dalam persaingan.

3. Model pengembangan produk dalam upaya mengembangkan produk ritel yang dapat memiliki nilai jual lebih dari pesaing.

4. Pendampingan membuat kemasan produk ritel yang disesuaikan dengan jenis produk yang dijual, dan dibuat menggunakan bahan kain yang tahan lama dan memiliki variasi warna yang beragam dan juga berfungsi sebagai tas dan lebih ramah lingkungan.

\section{B. Saran}

Perbaikan secara berkelanjutan usaha ritel dapat dulakukan antara lain dapat dikembangkan dalam kajian selanjutnya.

1. Meningkatkan keunggulan bersain dengan produk yang lebih unik dibandingkan pesaing.

2. Keunggulan differensiasi pada Toko Mimi Fashion perlu terus ditingkatkan.

3. Meningkatkan nilai tambah produk melalui kemasan berupa tas belanja yang sudah diberikan Tim PKM untuk terus dipertahankan.

\section{Ucapan Terima Kasih}

Kepada Direktur dan Staff DPPM Universitas Tarumanagara yang telah memberikan dukungan sehingga PKM ini terselesaikan.

\section{REFERENSI}

Berman, Barry and Joel R. Evans (2007), Retail Management: A Strategic Approach, 10th ed., Prentice Hall

Davidson, R.William.,(1998)," Retailing Management," 6e. Canada : John Wiley \& Son, Inc, 
Levy, G., dan Weitz.(2014). Retailing Management.9th Edition. New York: McGraw-Hill. Morgan, Robert M and Shelby D. Hunt, (1995) "The Commitment Trust Theory Of Relationship Marketing”, Journal Of Marketing, 58 July, 20-38.

Porter, Michael E, 1990. The Competitive Advantage of Nation, The Free Press. 